\title{
Effect of Various Plant Morphological Characters against Population Fluctuation of Major Pests Occurring on Different Varieties of Field Pea (Pisum sativum L.)
}

\author{
S. Pal ${ }^{1}$, S. Samanta ${ }^{1}$ and A. Banerjee ${ }^{2}$ \\ ${ }^{1}$ Department of Agricultural Entomology, Bidhan Chandra Krishi Viswavidyalaya, \\ Mohanpur, Nadia-741252, West Bengal, India \\ ${ }^{2}$ AICRP on MULLaRP, Directorate of Research, Bidhan Chandra Krishi Viswavidyalaya, \\ Kalyani, Nadia-741235, West Bengal, India \\ *Corresponding author
}

\section{A B S T R A C T}

\section{Keywords}

Field pea, Pisum sativum, Gram pod borer, Pulse aphid, Plant morphological characters

Article Info

Accepted:

10 July 2020

Available Online:

10 August 2020
A field experiment was conducted in 'A-B' Block Farm of BCKV during rabi seasons of two consecutive years 2017-18 and 2018-19 to study the effect of various plant morphological characters against population fluctuation of major pests occurring on different varieties of field pea (Pisum sativum L.).Aphid population varied from 0.26 per plant to 2.08 per plant in first year and the range was 1.23 to 3.99 per plant during second year, while the larval population of gram pod borer varied from 0.24 to 1.57 per plant in first year and from 0.01 to 0.38 per plant in second year. Pod damaged ranged from 7.20 to 31.17 per cent in first year and the range was 0.29 to 21.87 per cent in second year. Gram pod borer population showed significant and positive correlation with plant height and number of seeds per pod among different plant morphological parameters during both seasons. However, only number of number of primary branches per plant showed significant and positive correlation with aphid infestation. Multiple step wise linear regression study revealed that plant height was the sole influencing factor over the intensity of larval population of gram pod borer and number of primary branches per plant was the sole influencing factor over the infestation of aphid during both seasons.

\section{Introduction}

Field pea or pea, Pisum sativum L. $(2 \mathrm{n}=2 \mathrm{x}=14)$, commercially grown worldwide, is generally used as vegetable as well as pulse crop (Dhar et al., 2001). It is highly nutritive containing high proportion of digestible proteins, carbohydrates, minerals and vitamins. One hundred gram of dried edible portion of pea seed contains 62.1g carbohydrates, $22.5 \mathrm{~g}$ protein, $1.8 \mathrm{~g}$ fat, $64 \mathrm{mg}$ calcium, $4.8 \mathrm{mg}$ iron, $0.15 \mathrm{mg}$ riboflavin, 
$0.72 \mathrm{mg}$ thiamin and $2.4 \mathrm{mg}$ niacin (Gueguen and Barbot, 1988; Swiątecka et al., 2010; Dahl et al., 2012). Bijjur and Verma (1995) reported 57 species of insect pests which attack pea crop, with an annual monetary loss of 540 million Indian rupees. Pea pod borer (Etiella zinckenella) and gram pod borer (Helicoverpa armigera) are the major pests of field pea causing as high as $50.9 \%$ pod infestation with $77.64 \%$ seed damage resulting in $23.9 \%$ loss in the seed yield (Yadav and Patel, 2015). Kushwaha (2002) recorded 9 insect pests on pea crop at different stages of its growth and estimated losses ranged from 13 to 17 percent in Jabalpur, Madhya Pradesh and these were Aphis craccivora, Melanogromy zaphaseoli, Phytomyza atriconis, Caliothrips indicus, Plusia orichalcea, Helicoverpa armigera, Etiella zinckenella, Melanagromyza obtusa, Spodoptera litura. The prevention of crop losses from pest attack is necessary for resulting massive production of higher yielding potential of the new pea varieties. The physio-morphic characters of plants can affect the population growth, reproduction and survival of insect herbivore (Kareiva and Sahakian, 1990; Soroka and MacKay, 1990). There are several possible mechanisms through which plant morphology could affect herbivore performance. Plant architecture may cause reduced movements and increased crowding of herbivores therefore may alter the effective per capita access to resources (Dixon, 1973).

Soroka and MacKay (1990) reported that there is a strong influence of pea architecture on aphid population growth. Therefore, host plant resistance is an efficient method of crop protection and may provide a viable tactic for managing the major pests viz. gram pod borer (Helicoverpa armigera Hub.) and pulse aphid (Aphis craccivora Koch.) occurring on peas by developing resistance cultivars. Keeping in view the significance of pea the present research work was directed to explore the role of morphological characters of pea cultivars against major insect pests.

\section{Materials and Methods}

The field experiment was conducted at 'A-B' Block Farm of Bidhan Chandra Krishi Viswavidyalaya, Kalyani, Nadia, West Bengal to evaluate the role of morphological characteristics of selected field pea varieties viz., Rachna, IFPD 122, IFP 17-18, KPMR 935, HFP 1428, IFP 5-19, NDPT 2017-06, RFP 11-09, HUDP 15, HFP 990-7B against infestation of gram pod borer and pulse aphid. The experiment was conducted in Randomized Block Design with 3 replications during two consecutive rabi seasons of 201718and 2018-2019. The observations were taken from three weeks after sowing and continued till maturity of the crop. From each treatment randomly four plants were selected as sample plants and tagged with the help of paper card. The observations were taken at weekly intervals. At each observation total number of gram pod borer larvae per plant and in case of aphid total number of adults and nymphs in $10 \mathrm{~cm}$ apical twig per plant from the sampled plants were recorded and overall mean population was calculated. To study the effect of different morphological characters on tolerance or susceptibility of pea varieties against gram pod borer and aphid infestation various plant morphological data were recorded from the sampled plants during crop growth period.

The morphological characters taken into consideration were plant height (by measuring the height from the ground level to the top of the plant canopy with the help of an ordinary meter scale at $50 \%$ flowering time), number of primary branches per plant (by counting the branches arising from the basal nodes at $50 \%$ flowering time), days to $50 \%$ flowering (by recording number of days required for 
flowering of $50 \%$ plant), days to maturity (by recording number of days required from the sowing of seeds to pod maturation), number of pods per plant (by counting the number of filled pods per plant at harvesting time), pod length (by measuring the length of mature and full grown pod using centimeter scale at harvesting time), number of seeds per pod (by counting the number of seeds per matured pod at harvesting time).Percent pod damage after harvesting was calculated using the following formula:

Pod damage $\%=($ Total pods per plant $/$ Damaged pods per plant) x100

Thereafter, correlation and multiple step wise linear regression were worked out between the mean population of gram pod borer and pulse aphid with the aforementioned plant morphological parameters by using the software IBM SPSS20.0.

\section{Results and Discussion}

Incidence of pulse aphid and gram pod borer on different varieties of field pea

Aphid population differed significantly among themselves in respect of the test varieties in both the years of experimentation. During first year the significantly highest population was recorded in variety IFP 5-19 (2.08/ plant) and IFP 17-18 (1.97/ plant) where both of them were statistically at par (Table 1). And the significantly lowest pest population was observed in Rachna (0.26/ plant) and HFP1428 (0.59/ plant), where also both of them were statistically at par. However, in second year, significantly highest aphid population was recorded in KPMR 935 (3.99/ plant) and HFP 9907B (3.75/ plant) but the lowest population was observed in Rachna (1.23/ plant) followed by HFP 1428 (1.74/ plant) like previous year (Table 2).

The pod borer population also showed significant differences among the test varieties in two years. During first year, the variety HFP 9907B (1.57 larvae/ plant) was recorded as the most susceptible variety followed by NDPT 2017-06 (1.29 larvae/ plant) (Table 1). On the other hand, Rachna (0.24 larvae/ plant) was found as the least susceptible variety followed by HFP 1428 (0.57 larvae/ plant). Significant differences existed among the pod borer population recorded within HFP 9907B and NDPT 201706 as well as within Rachna and HFP 1428. During second year, among screened varieties, HFP 9907B (0.38 larvae/ plant) recorded significantly highest pod borer population followed by NDPT 2017-06 (0.32 larvae/ plant), though the pest population among these two varieties were statistically at par (Table 2). Like previous year, Rachna (0.01 larvae/ plant) recorded the least pest population followed by HFP 1428 (0.04 larvae/ plant), but the population were statistically at par.

\section{Pod damage in different varieties of field pea}

The analyzed data of percent pod damage in different test varieties of field pea due to pod borer is presented in Table 1, Table 2 and Figure 1. During first year, the pod damage ranged from 7.20 to $31.17 \%$. The damage was significantly lowest in Rachna (7.20\%) followed by HFP 1428 (11.80\%) while, the variety HFP 9907B recorded the highest pod damage $(31.17 \%)$ followed by NDPT 201706 (19.90\%).During second year, the pod damage ranged from 0.29 to $21.87 \%$. Similar trend was noticed in both the years of study regarding exhibiting pod damage. Significantly lowest pod damage was recorded in Rachna $(0.29 \%)$ followed by HFP 1428 (1.88\%) while, HFP 9907B (21.87\%) recorded the highest pod damage.

From the two years of experimentation regarding incidence of pod borer and their 
pod boring ability, it can be concluded that among the test varieties, HFP 9907B was the most susceptible variety to the pod borer and Rachna was the least susceptible.

Influence of plant morphological characters on incidence of major pests occurring on field pea

Influence of various plant morphological characteristics of selected field pea varieties on the incidence of gram pod borer and pulse aphid during both the years of experimentation are presented below.

\section{Influence of plant height on incidence of major pests}

During first year, significantly highest plant height was observed in NDPT 2017-06 $(110.05 \mathrm{~cm})$ followed by IFP 5-19 $(87.05 \mathrm{~cm})$ while, lowest plant height was recorded in Rachna $(51.05 \mathrm{~cm})$ which was at par with HFP 14-28 (51.95 cm) (Table 1). During second year mean plant height varies from $50.75 \mathrm{~cm}$ to $113.64 \mathrm{~cm}$ (Table 2).Maximum and minimum plant height was observed in varieties NDPT 2017-06 and Rachna, respectively.

The present study showed that there was a significant and positive correlation between plant height and pod borer population $(\mathrm{r}=$ 0.673 and 0.696) (Table 3) which is partially in support with the studies of Roshan and Raju (2018) who observed positive but nonsignificant relationship between plant height and percent pod damage in chick pea. In case of aphid non-significant and positive correlation was found $(r=0.413$ and 0.048$)$ during both of the seasons. This result differs from the findings of Cartier and Auclair (1964), who recorded maximum pea aphid abundance on shorter plants as compared to taller ones, though, Legrand and Barbosa (2000) reported no significant effect of plant architecture on population growth rate of pea aphids in countries outside India.

\section{Influence of number of primary branches on incidence of major pests}

During 2017-18, maximum number of primary branches per plant was recorded on KPMR 935 (3.05) which differed significantly from rest of the varieties while, minimum number of primary branches were recorded on HFP 14-28 (0.50) followed by IFP 519 (0.74) (Table 1). During second year also, significantly highest number of primary branches per plant was recorded on KPMR 935 (3.26) (Table 2). However, in this season, minimum number of primary branches per plant was recorded on Rachna (0.25) followed by IFPD 122 (0.74), HFP 14-28 (0.75) and IFP 519 (0.76) where last three values were statistically at par.

It is evident from correlation studies, number of primary branches per plant was positively and non-significantly correlated $(r=0.452$ and 0.466 ) with the pod borer population during both of the season (Table 3). The present findings support the finding of Hasan et al., (2008) who also obtained a positive relation between pod borer infestation and number of branches per plant, though the association was significant. However, in case of aphid it was positively and significantly correlated(r= 0.928 and 0.642 ). This result is in conformity with those of Dixon (1973), Day (1986) and Klindman and Dixon (1996), all of them reported that less plant surface area could increase aphid aggregation and intra-specific competition among them leading to mortality and lower reproductive success.

\section{Influence of days to $50 \%$ flowering on incidence of major pests}

Number of days required for fifty percent flowering varied from 62.31 to 70.13 during 2017-18. Maximum number of days were required in variety IFP 5-19 (70.13) which 
was at par with IFP 17-18 (70.12) while, minimum number of days were required in Rachna (62.31) which was at par with HFP 9907B (62.34) and HUDP 15 (62.39) (Table 1). However, during 2018-19, the highest number of days required for fifty per cent flowering was recorded in variety NDPT 2017-06 (72.21) which was statistically at par with IFP 5-19 (71.96) and the period was significantly lowest in KPMR 935 (62.16 days) followed by IFPD 122 (63.23 days) and HUDP 15 (64.13 days) (Table 2).

The correlation studies revealed that fifty percent flowering shows positive and nonsignificant relation with pod borer $(\mathrm{r}=0.093$ and 0.187) and aphid ( $\mathrm{r}=0.349$ and 0.059) population during 2017-18 and 2018-19, respectively (Table 3 ).

\section{Influence of days to maturity on incidence of major pests}

During first year, mean number of days required for maturation of pods in different varieties varied from 108.05 to 120.23 (Table 1). Among the test varieties, KPMR 935 required significantly maximum time for pod maturation, on the other hand variety IFP 1718 required minimum time which was at par with IFPD 122 (108.15 days). However, during second year variety NDPT 2017-06 required maximum time (115.26 days) for maturation followed by IFP 519 (113.23 days) and minimum time was recorded in variety Rachna (105.12 days) which was at par with HUDP 15 (105.22 days) (Table 2).

During two years of experimentation a nonsignificant and positive correlation was observed between pod maturity and pest maturity $(\mathrm{r}=0.344$ and 0.485 in case of pod borer and $\mathrm{r}=0.348$ and 0.363 in case of aphid, respectively) (Table 3).

Lal et al., (1981) also reported that the late maturing varieties are more susceptible to pod borer than the early ones, though their test crop was pigeon pea.

\section{Influence of number of pods per plant on incidence of major pests}

In 2017-18, highest number of pods per plant was recorded in variety IFPD122(11.00) which was statistically at par with NDPT 2017-06 (10.05) whereas, significantly lowest number of pods per plant was recorded in Rachna (6.25) which was statistically at par with IFP 17-18 (7.28) (Table 1). During 201819, IFP 519 had highest number of pods per plant i.e. 12.00 followed by NDPT 2017-06 (11.00) and minimum number of pods per plant was recorded in Rachna (6.75) like previous year (Table 2).

The correlation studies revealed that total number of pods per plant in different varieties of pea had non-significant and positive relation with pod borer $(\mathrm{r}=0.467$ and 0.465$)$ and aphids ( $\mathrm{r}=0.198$ and 0.103$)$, respectively (Table 3). Roshan and Raju (2018) also obtained a positive and non-significant relation between total number of pod per plant and percent pod damage due to pod borer but their test crop was chick pea.

\section{Influence of pod length on incidence of major pests}

During first year significantly highest pod length was observed in NDPT 2017-06 (6.87 $\mathrm{cm})$ while minimum pod length was recorded in RFP 11-09 $(5.01 \mathrm{~cm})$ followed by HFP 9907B $(5.02 \mathrm{~cm})$ and Rachna $(5.05 \mathrm{~cm})$ which did not differ significantly (Table 1).

During second year the highest pod length was recorded also in NDPT 2017-06 (6.81 $\mathrm{cm})$, though the lowest was recorded in KPMR $935(5.02 \mathrm{~cm})$ followed by Rachna $(5.25 \mathrm{~cm})$ which were at par with each other (Table 2). 
Table.1 Incidence of major pests of field pea along with different plant morphological characters during 2017-18

\begin{tabular}{|c|c|c|c|c|c|c|c|c|c|c|}
\hline Variety & $\begin{array}{c}\text { Mean } \\
\text { population } \\
\text { of pulse } \\
\text { aphid/ plant }\end{array}$ & $\begin{array}{c}\text { Mean } \\
\text { population } \\
\text { of pod } \\
\text { borer/ plant }\end{array}$ & $\begin{array}{c}\% \text { Pod } \\
\text { damage }\end{array}$ & $\begin{array}{c}\text { Plant } \\
\text { height } \\
(\mathrm{cm})\end{array}$ & $\begin{array}{l}\text { No. of } \\
\text { primary } \\
\text { branches } \\
\text { / plant }\end{array}$ & $\begin{array}{c}\text { Days to } \\
50 \% \\
\text { flowering }\end{array}$ & $\begin{array}{l}\text { Days to } \\
\text { maturity }\end{array}$ & $\begin{array}{c}\text { No. } \\
\text { of } \\
\text { pods/ } \\
\text { plant }\end{array}$ & $\begin{array}{l}\text { Pod } \\
\text { length } \\
(\mathrm{cm})\end{array}$ & $\begin{array}{c}\text { No. of } \\
\text { seeds } \\
\text { /pod }\end{array}$ \\
\hline Rachna & 0.26 & 0.24 & 7.20 & 51.05 & 1.25 & 62.31 & 110.10 & 6.25 & 5.05 & 5.02 \\
\hline IFP 17-18 & 1.97 & 1.14 & 18.54 & 80.50 & 2.10 & 70.12 & 108.05 & 7.28 & 5.95 & 7.25 \\
\hline HFP 1428 & 0.59 & 0.57 & 11.80 & 51.95 & 0.50 & 65.20 & 112.26 & 8.05 & 5.27 & 6.45 \\
\hline NDPT 2017-06 & 1.73 & 1.29 & 19.90 & 110.05 & 2.05 & 64.08 & 118.14 & 10.05 & 6.87 & 7.51 \\
\hline HFP 9907B & 1.39 & 1.57 & 31.17 & 70.25 & 1.51 & 62.34 & 112.08 & 8.02 & 5.02 & 7.02 \\
\hline IFPD 122 & 1.57 & 0.75 & 13.63 & 60.55 & 1.05 & 65.16 & 108.15 & 11.00 & 6.00 & 4.95 \\
\hline KPMR 935 & 1.04 & 1.06 & 16.43 & 58.21 & 3.05 & 68.02 & 120.23 & 9.25 & 6.21 & 6.85 \\
\hline IFP 5-19 & 2.08 & 0.95 & 14.67 & 87.05 & 0.74 & 70.13 & 115.02 & 9.95 & 5.58 & 5.00 \\
\hline RFP 11-09 & 0.85 & 0.70 & 12.73 & 55.35 & 1.52 & 68.02 & 110.14 & 7.85 & 5.01 & 4.01 \\
\hline HUDP 15 & 1.25 & 0.84 & 13.85 & 65.28 & 1.08 & 62.39 & 115.32 & 9.02 & 5.84 & 5.05 \\
\hline $\operatorname{SEm}(+/-)$ & 0.12 & 0.02 & 0.70 & 0.69 & 0.06 & 0.49 & 0.66 & 0.54 & 0.11 & 0.14 \\
\hline $\mathrm{CD}(\mathrm{P}=\mathbf{0 . 0 5})$ & 0.36 & 0.08 & 2.10 & 2.05 & 0.19 & 1.45 & 1.96 & 1.60 & 0.34 & 0.42 \\
\hline
\end{tabular}


Table.2 Incidence of major pests of field pea along with different plant morphological characters during 2018-19

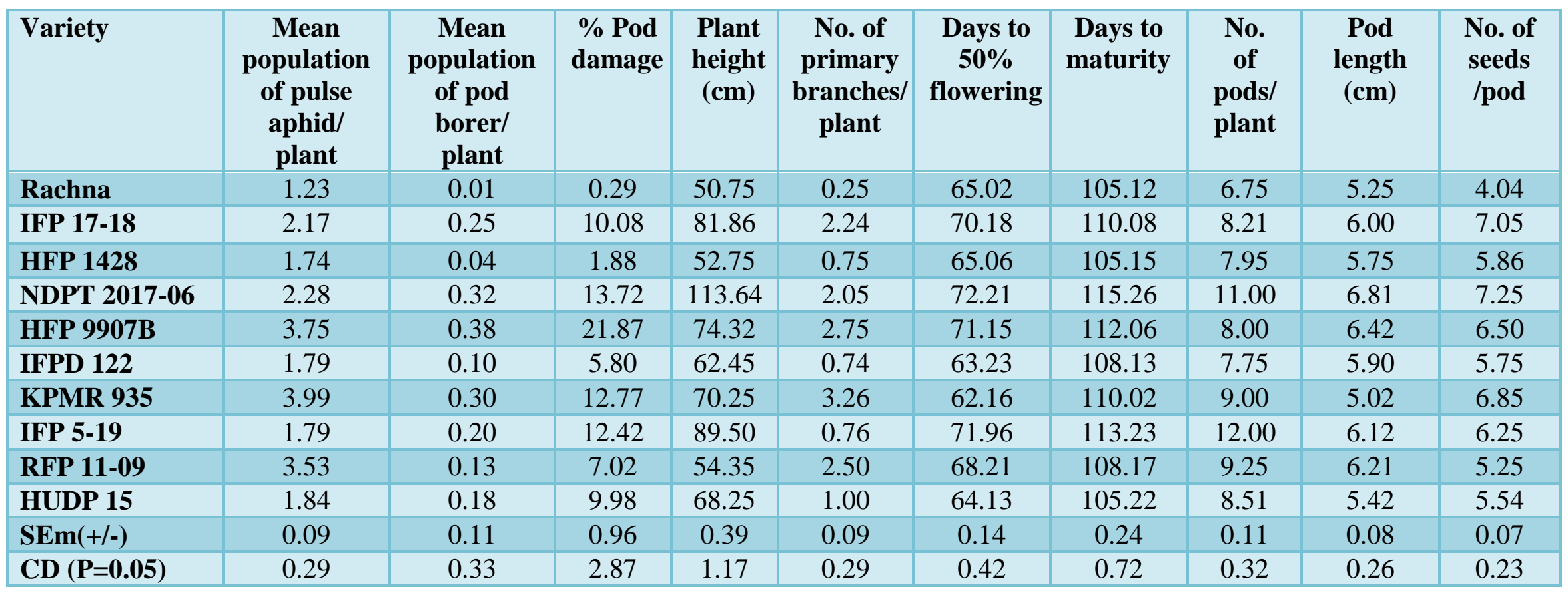

Table.3 Correlation between pest population and plant morphological characters of field pea

\begin{tabular}{|c|c|c|c|c|c|c|c|c|}
\hline \multirow[t]{2}{*}{ Name of insect pest } & \multirow{2}{*}{$\begin{array}{c}\text { Year of } \\
\text { study }\end{array}$} & \multicolumn{7}{|c|}{ Correlation coefficient values ( $r$ ) in respect to different plant morphological parameters } \\
\hline & & $\begin{array}{l}\text { Plant } \\
\text { height }\end{array}$ & $\begin{array}{l}\text { No. of primary } \\
\text { branches/ plant }\end{array}$ & $\begin{array}{c}\text { Days to } 50 \% \\
\text { flowering }\end{array}$ & $\begin{array}{l}\text { Days to } \\
\text { maturity }\end{array}$ & $\begin{array}{c}\text { No. } \\
\text { of pods/ } \\
\text { plant }\end{array}$ & $\begin{array}{l}\text { Pod } \\
\text { length }\end{array}$ & $\begin{array}{c}\text { No. of } \\
\text { seeds/ } \\
\text { pod }\end{array}$ \\
\hline Pod borer & 2018-19 & $0.696 *$ & 0.466 & 0.187 & 0.485 & 0.465 & 0.452 & $0.604 *$ \\
\hline Pulse aphid & 2017-18 & 0.413 & $0.928 *$ & 0.349 & 0.348 & 0.198 & 0.530 & 0.520 \\
\hline
\end{tabular}

* Significance at 5\% level in two tail 
Table.4 Multiple step-wise linear regression results for explaining pest population recorded infield pea on the basis of various plant morphological characters during 2017-18 and 2018-19

\begin{tabular}{|c|c|c|c|c|c|}
\hline $\begin{array}{l}\text { Name of } \\
\text { insect pest }\end{array}$ & $\begin{array}{c}\text { Year of } \\
\text { study }\end{array}$ & Regression equation & $R^{2}$ value & Parameters & Remarks \\
\hline \multirow[t]{2}{*}{ Pod borer } & $2017-18$ & $\mathrm{Y}=0.039+0.012 \mathrm{X}_{1}^{*}$ & $\mathrm{R}^{2}=0.477$ & $\begin{array}{l}Y=\text { pest population, } \\
\mathrm{X}_{1}=\text { plant height }\end{array}$ & \multirow{2}{*}{$\begin{array}{l}\text { Plant height becomes the sole } \\
\text { influencing factor over larva } \\
\text { population of pod borer } \\
\text { population. }\end{array}$} \\
\hline & 2018-19 & $Y=0.405+0.004 X_{1}^{*}$ & $\mathrm{R}^{2}=0.476$ & $\begin{array}{l}\mathrm{Y}=\text { pest population, } \\
\mathrm{X}_{1}=\text { plant height }\end{array}$ & \\
\hline \multirow[t]{2}{*}{$\begin{array}{l}\text { Pulse } \\
\text { aphid }\end{array}$} & $2017-18$ & $\mathrm{Y}=0.960+0.240 \mathrm{X}_{1}^{* *}$ & $\mathrm{R}^{2}=0.602$ & $\begin{array}{l}Y=\text { pest population, } \\
X_{1}=\text { number of } \\
\text { primary branches per plant }\end{array}$ & \multirow{2}{*}{$\begin{array}{l}\text { Number of primary branches } \\
\text { per plant becomes the sole } \\
\text { influencing factor over aphic } \\
\text { population. }\end{array}$} \\
\hline & 2018-19 & $\mathrm{Y}=1.279+0.739 \mathrm{X}_{1}^{*}$ & $\mathrm{R}^{2}=0.467$ & $\begin{array}{l}Y=\text { pest population, } \\
X_{1}=\text { number of } \\
\text { primary branches per plant }\end{array}$ & \\
\hline
\end{tabular}

** Significance at $1 \%$ level in two tail * Significance at $5 \%$ level in two tail

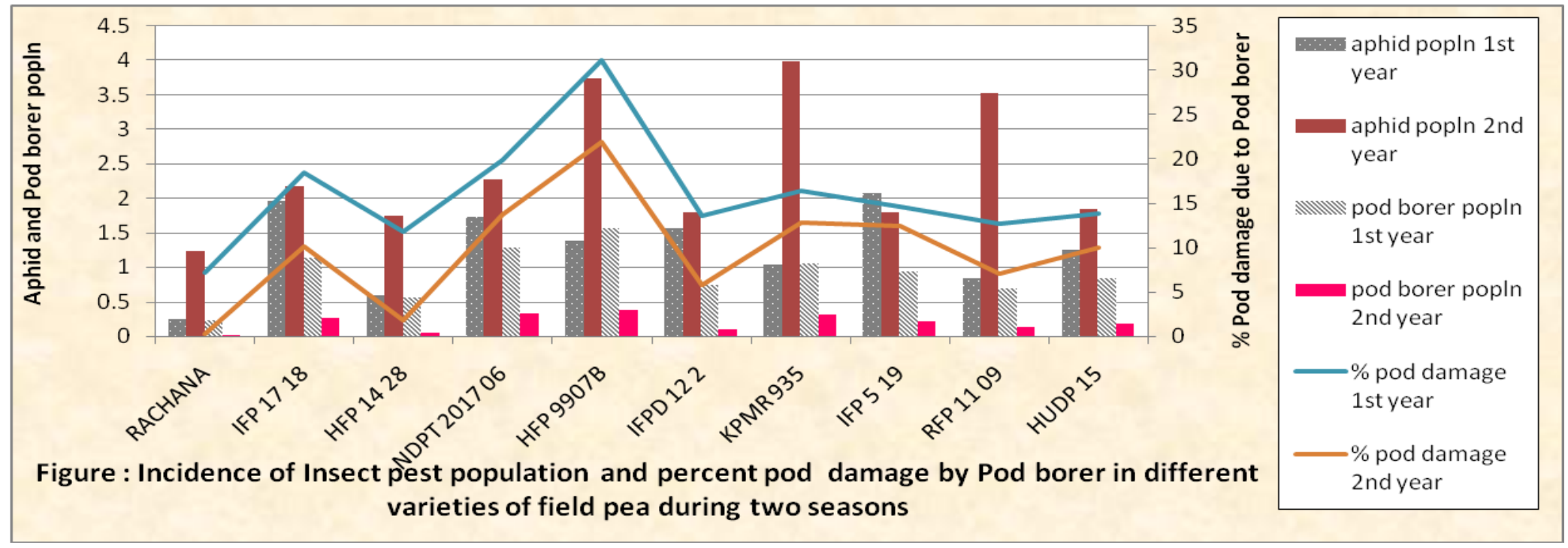


Pod length was non-significantly and positively correlated with the pod borer $(\mathrm{r}=$ 0.377 and 0.452$)$ and aphid $(r=0.530$ and 0.107 ) population during both the seasons. Kanchana et al., (2015) also reported a positive correlation between pod length and pod borer population in chickpea.

\section{Influence of number of seeds per pod on incidence of major pests}

Significantly highest number of seeds per pod was recorded in NDPT 2017-06 (7.51)which was statistically at par with IFP 17-18 (7.25) whereas, the lowest number of seeds was recorded in varieties RFP 11-09 (4.01) followed by IFPD 122 (4.95) during first year (Table 1). Similar trend was followed in second year where, significantly highest number of seeds per pod was recorded in NDPT 2017-06 (7.25) followed by IFP 17-18 (7.05) though the lowest number of seeds was recorded in variety Rachna (4.04) followed by RFP 11-09 (5.25) (Table 2).

The correlation studies revealed that total number of seeds per pod showed positive and significant relation with pod borer $(\mathrm{r}=$ 0.654 and 0.604 ) though the association was positive but non-significant in case of aphid $(\mathrm{r}=0.520$ and 0.405$)$ during both the years of study (Table 3 ).

Multiple step-wise linear regression model as presented in Table 4 showed that the pest population was significantly influenced by plant morphological parameters. Among various plant morphological parameters taken into consideration, plant height was the sole influencing factor over the intensity of gram pod borer population on field pea during both seasons. The multiple regression coefficients of the two seasons $\left(\mathrm{R}^{2}=0.477\right.$ and 0.476 , respectively) explained that plant height describes pod borer population up to
$47.7 \%$ and $47.6 \%$, respectively during two seasons. However, the aphid incidence in relation to plant morphological parameters as assessed by regression study revealed that number of primary branches per plant was the sole influencing factor over the intensity of aphid population on field pea during both seasons. The multiple regression coefficients of the two seasons $\left(\mathrm{R}^{2}=0.602\right.$ and 0.467 , respectively) explained that number of primary branch per plant describes aphid population up to $60.2 \%$ and $46.7 \%$, respectively during two seasons.

From this study, it can be concluded that pod borer population was significantly and positively correlated with plant height and number of seeds per pod during both seasons whereas, pulse aphid population was significantly and positively correlated with number of primary branches per plant. From the multiple step wise linear regression it can be stated that plant height was the sole influencing factor over the intensity of larval population of pod borer and number of primary branches per plant was the sole influencing factor over the infestation of aphid during both seasons.

\section{Acknowledgements}

We would like to thanks Dr. Amitava Banerjee for his unreserved efforts at the time of data collection in the field. The research was supported by grants from the AICRP on MULLaRP.

\section{References}

Bijjur, S. and S. Verma. 1995. Effect of abiotic factors on the pests of pea and natural enemies. Indian Journal of Enomology, 57(3): 233-239.

Cartier, J.J. and L. Auclair. 1964. Pea aphid behavior: color preference on a chemical diet. Canadian Entomologist.96: 1240- 
1243.

Dahl, W.J., L.M. Foster and R.T. Tyler. 2012. Review of the health benefits of peas (Pisum sativum L.). British Journal of Nutrition, 108: S3-S10.

Day, K.R. 1986. Population growth and spatial patterns of spruce aphids (Elatobium abietinum) on individual trees. Journal of Applied Entomology. 102: 505-515.

Dhar, S.S., G. Singh., A. Yadav., V. Mittal., D.V. Singh and B. Singh. 2001. Seasonal incidence of the pod borers, Etiella zinckenella (Treitschke) and Helicoverpa armigera (Hubner) on vegetable pea in Meerut. Annals of Horticulture, 4(1): 89-94.

Dhar, V. andN.B. Singh.2001. Status of Pigeonpea Research in India. In: Proceeding of National Symposium on Pulses for Sustainable Agriculture and Nutritional Security held on April 1719, 2001 at New Delhi. pp. 73-76.

Dixon, A.F.G. 1973. Biology of aphids. Camelot Press, London, United Kingdom.

Gueguen, J. and J. Barbot. 1988. Quantitative and qualitative variability of pea (Pisum sativum L.) protein composition. Journal of the Science of Food and Agriculture.42: 209-224.

Hasan, M. K., M. J. Alam and M. Kamruzzaman. 2008. Screening of some chickpea genotypes against Helicoverpa armigera on the basis of physical parameters grown at two locations of Bangladesh. Journal of Agroforestry and Environment.2(2): 183-186.

Kanchana, R., K.V. Lakshmi and P.R.Sekhar. 2015 Morphological and biochemical bases of host plant resistance to Helicoverpa armigera (Hubner) in chickpea. Journal of Plant Protection and Environment. 2(1):1217.

Kareiva, P. and R. Sahakian.1990.Tritrophic effects of simple architectural mutation in pea plants. Nature (Lond.).345: 433434.

Klindman, P. and A.F.G. Dixon. 1996. Population dynamics of a tree-dwelling aphid: individuals to populations. Ecological Modelling.89: 23-30.

Kushwaha, K. 2002. Succession of insect pests of pea. M. Sc. (Ag.) Thesis submitted to JNKVV, Jabalpur, M.P.

Lal, S. S., C.P. Yadav and C.A.R. Dias.1981. Major pest of pigeon pea in Uttar Pradesh, India. International pigeonpea Newsletter. 1:30-31.

Legrand, A. and P. Barbosa. 2000. Pea aphid (Homoptera: Aphididae) fecundity, rate of increase, and within-plant distribution unaffected by plant morphology. Environmental Entomology.29: 987993.

RakshithRoshan, D. and S.V.S. Raju.2018. Influence of Morphological Characters of Chickpea Varieties on Damage by Gram Pod Borer (Helicoverpa armigera Hubner). International Journal of Current Microbiology and Applied Science. 7(12): 2025-2033.

Soroka, J. J. and P. A. Mac Kay. 1990. Seasonal occurrence of the pea aphid, Acyrthosiphonpisum (Harris) (Homoptera: Aphiddidae), on cultivars of Peld peas in Manitoba and its effects on pea growth and yield. Canadian Entomologist.122: 503-513.

Światecka, D., A.Światecki, H.Kostyra, F.K. Marciniak-Darmochwa andE. Kostyra. 2010. The impact of pea protein hydrolysates on bacterial physiological activity - An in vitro study. International Journal of Food Microbiology, 140(2-3): 263-270.

Yadav, S.K. and S. Patel. 2015. Insect-pest complex on Pisum sativum L. and their natural enemies at pantnagar. Journal of Plant Development Sciences, 7(11): 839-841. 


\section{How to cite this article:}

Pal, S., S. Samanta and Banerjee, A. 2020. Effect of Various Plant Morphological Characters against Population Fluctuation of Major Pests Occurring on Different Varieties of Field Pea (Pisum sativum L.). Int.J.Curr.Microbiol.App.Sci. 9(08): 29-39.

doi: https://doi.org/10.20546/ijcmas.2020.908.004 